\title{
A Review of Reasons and Backgrounds of Arab Extremists' Unrealistic Claims about the Name of "Persian Gulf"
}

\author{
Reza Piramoun Sharifabad \\ BA in Russian Translation \\ Department of Russian Language \\ Ferdowsi University of Mashhad \\ Dr. Hossein-Ali Mostafavi \\ Assistant Professor \\ Department of Russian Language \\ Ferdowsi University of Mashhad
}

\begin{abstract}
The present research aims to study the reasons and backgrounds of Arabs extremists' unrealistic claims about the name of Persian Gulf and their attempts to use a forged name "Arabian Gulf" instead of its true name. First, the geographical location and the features of the Persian Gulf are outlined. Next, the disagreement over changing the name is discussed and the background of the name of Persian Gulf and difference of opinions over the origin of distortion are reviewed. Then, four of the most important reasons for the distortion of this name are mentioned and finally, we will offer some suggestions and initiatives in order to stabilize and uphold the name of the Persian Gulf.
\end{abstract}

Keywords: Persian Gulf, Distortion of name, Reasons and Backgrounds, Arab Extremists, The Forged name "Arabian Gulf".

\section{INTRODUCTION}

There have been continuous disputes over the name of "Persian Gulf" in the past decades, during which the colonialist countries have played a major role, especially the UK. Since many studies have been conducted by scholars and researchers to firmly prove the true name "Persian Gulf" and reject the forged name "Arabian Gulf", the present research will suffice to examine the reasons and backgrounds behind this false name, thus refusing to represent the relevant historical maps and deeds. Suggesting a series of actions to neutralize the distorters' activities is among the author's motivations to do the research.

\subsection{The Persian Gulf's Geographical Location and Features}

The Persian Gulf embeds around $62 \%$ of the earth's surface waters. Its water is saltier than other seas because of the salt contents carried by the rivers which flow to the Persian Gulf's body of water and also the high amount of evaporation.

In 2002, the oil and gas reserves of Persian Gulf were estimated to be 565 billion $\mathrm{m}^{3}$ which is $63 \%$ of the total amount of the world's reserves. Also, the region's natural gas reserves were estimated up to 21 million $\mathrm{m}^{3}$ which forms $30 \%$ of the total amount of the world's natural gas [1].Other significant features of the Persian Gulf include oysters containing beautiful pearls and also the strategic islands Abu Musa, Greater Tunb, and Lesser Tunb.

\section{DISCUSSION}

A number of natural and legal persons in Arab countries disagree with the idea of changing the name of Persian Gulf and believe this name has been historically recognized and used by the Arab world since the advent of Islam. Despite all changes and incidents in the region during the past centuries, the name remained unchanged. If there had been a necessity for changing the name, it could have happened in the early years of Islam at the time of Rashidun Caliphs [2]. 
The necessity for the integrity and unity in writing geographical names and prevention of any ambiguity or multiplicity forced the UN to establish a legal foundation ${ }^{1}$. In 1967 , the first conference on the standardization of geographical names was held in Geneva with the participation of scientific and administrative commissions. In the same conference (Geneva), all the Arab countries strongly disagreed with the Israel's suggestion for changing the name "Gulf of Aqaba", calling it an improper action. Other countries supported the Arab nations' concept and finally Israel withdrew its request [3]. From a legal perspective, this action by the Arab countries can be used against themselves in a similar case. "Since 1971 when the incomplete phrase "the Gulf" was first used by the UN, 14 notes were sent from Iran's representatives to the UN up until 1979 [4].

\subsection{Naming Background of the Persian Gulf}

"The Red Sea was introduced as the Arabian Gulf by Herodotos. In the world map Hecataeus (472 to 509 B.C), the Persian Gulf and Arabian Gulf (Red Sea) have been clearly shown. Also, in the world map of Diseark (285-347 B.C), the Persian Gulf and Arabian gulf are completely distinct". The ancient Greeks called Pars Sea as "Persian Gulf" and Red Sea as "Arabian Gulf" [4].

\subsection{The Origin of Attempts to Distort the Name of Persian Gulf}

According to many relevant studies, the origin of distortion dates back to $1960 \mathrm{~s}$, but whether the government of Britain or Arab countries first began the story requires further discussion. A group of researchers believe some Arab countries began to use the forged name with the spread of PanArabism. The Arabism ideology seeks to unite the Arab world by certain principles and policies. Some other assert that Charles Belgrave and Roderick Oven, the British government agents, used the forged name "Arabic Gulf" in their books for the first time, after which it spread to Arab countries, and we do not encounter such name even in the books or writings of the Arabs, except for some historians and geographers calling the Red Sea "Arabian Gulf [5]. In 1958, Abd al-Karim Qasim staged a coup in Iraq and claimed to be the leader of the Arab world, so he needed to propound the theory of foreign enemy in order to attract the Arab nations' interest and attention. At that time, the Arab world led by the Egyptian colonel Gamal Abdel Nasser was engaged in a conflict with Israel [6]. By changing the names "Persian Gulf" and "Khuzestan", Abdel Nasser resolved to introduce Iran as a new enemy to the Arab world in order to direct attention from Cairo to Bagdad. He used this political game with history and geography as a pretext for creating a division between the Arab nations and Iran. However, since the coup and violent policies of the colonels of Bagdad failed to interest Arabs, Abd al-Karim Qasim's propaganda found no place among them too [6]. Not only Kuwait, which used to be under the fear and political pressure of Bagdad, signed its contract of independence with Britain as "Al-khalij Al-Farsi" (Persian Gulf) in 1958, there have also been tens of deeds and maps published in Iraq which used the true name "Persian Gulf" [7].

\section{The Major Reasons for Distorting the Name "Persian Gulf"}

\subsection{The Disputes Between Iranians and Arabs Throughout History}

The relations between Iranians and Arabs before and after the advent of Islam clearly explain the background of these disputes. Before the rise of Islam and in the period of Jahiliyya ${ }^{2}$, the Arabs, deprived of any civilization, were either subordinate to the Persian Empire or Roman Empire. As Islam spread all over the region and Iran and brought bliss and honor to the Arabs, the behavior of Arab states, contrary to the true teachings and principles of Islam, was based on race and ethnicity. However, Iranians soon retrieved their independence and honor. Despite some interactions between Iranians and Arabs at the dawn of Islam, they had conflicts too, for which the racial discrimination policies of Umayyad Caliphs were the main reasons. The Umayyad Regime was founded in AD 661 and lasted for near a century. They revived the ethnic and racial privileges, formerly annulled by the teachings of Islam. The Umayyad Caliphs discriminated against non-Arabs, especially Iranians. Iranians' strong feeling of affection and devotion towards Ali ibn Abi Talib ${ }^{3}$ led to such discrimination. Despite the fact that Iranians warmly welcomed Islam, the aforementioned discrimination and unfair practice of Umayyad Caliphs triggered the conflicts [8].

\footnotetext{
${ }^{1}$ The United Nations Group of Experts on Geographical Names (UNGEGN)

2 the age of ignorance

${ }^{3}$ The first Imam of Shiite Muslims
} 


\subsection{The Arab Extremists; an Escape from Identity Crisis}

A part of this refers to the historical disputes between the two sides and the rest is related to the Arabs' historical identity. The extremist groups consider forging a historical identity as the easiest way to escape from lack of a valuable identity. The Arab extremists' attempts to distort the name "Persian Gulf" are rooted in an identity crisis. Lack of civilization before Islam is a notable example. As mentioned in the Quran ${ }^{1}$, in pre-Islamic Arabia, people used to bury alive female newborn infants because a daughter was considered a disgrace to the family. The Third Arab-Israeli War in 1967 which led to Israel's decisive victory and also the unfavorable image of Arabs presented by Hollywood made them frantically endeavor to revive their lost reputation in the world.

\subsection{Non-Arab Self-Seeking Institutes}

There are generally other groups that foment discord and benefit from it. Obviously, the project of distortion has been funded by petrodollars of Arab countries. A number of Western research institutes seized the opportunity and encouraged the regional Arab countries to advance the project. By providing forged deeds about the Persian Gulf, the aforementioned institutes would take a large amount of money.

Two of the noblest sciences, law and history, were manipulated in order to distort the name "Persian Gulf", hence, historians and legal experts were the most serious objectors to this distortion. In their view, invasion of a nation's history means a moral transgression and signifies downfall of values [8].

\subsection{The Arab world's Concern about Iran}

In recent years, Iran's effort to achieve the nuclear energy has caused some kind of fear in the Arab countries bordering the Persian Gulf which is the result of anti-Iran propaganda spread by the West, especially the US. Despite all peacemaking efforts of Iranian religious officials and politicians, Arab states are still concerned about Iran's power. Not only will this concern be assuaged, it might deteriorate as well by orations or statements. All negative points contained in the history of Islam or even before Islam such as being Arab or non-Arab, Shiite or Sunni, etc. have been fixed in their mind and constantly provoked by the colonialist powers. This fear of Iran, albeit delusional, has caused an alliance in the Arab nations and consequently the iterative claims over the ownership of the Islands Abu Musa, Greater Tunb, and Lesser Tunb and also distortion of the name Persian Gulf have been a major issue in the Middle East.

\section{CONCLUSiOn \& RECOMMENDATIONS}

\subsection{Initiatives to Stabilize and Uphold the Name of Persian Gulf}

In conclusion, there are 4 major reasons behind the distortion of Persian Gulf's name: (1) ArabIranian relations throughout history before and after Islam; (2) the Arabs seeking to repair their international image;(3) the self-seeking institutes funded by Arab extremists; (4) fear of a nuclear Iran. On the whole, any act of distortion is considered a kind of aggression which must be accordingly responded. As the final section, we note some actions which need to be taken in order to stabilize and uphold the name of Persian Gulf, while illuminating the issue to the general opinion in the world.

\subsection{Holding Multiple Conferences on the Persian Gulf}

Although considerable efforts have been made by Iranian scholars and intellectuals, more national and international conferences and research papers on the Persian Gulf are needed.

\subsection{Media Campaign}

Given that the mass media have a substantial effect on the audience's mind, it is suggested to launch a satellite channel named "Persian Gulf" broadcasting a wide range of news or documentaries with a focus on cultural and political events.

\subsection{Sports and Cultural Activities}

Setting up Iran Pro League with the new name "Persian Gulf Pro League" was one of the most proper decisions made by Iran Football League Organisation. Also, in the past years, a few friendly soccer

\footnotetext{
${ }^{1}$ Surah Takwir [81:9] \& Surah An-Nahl [16:58-59]
} 
cups were held with the name Persian Gulf Cup in which the neighboring countries participated. It is noteworthy that some soccer teams from Arab countries (which politically have claims on the name of Persian Gulf) actively took part in the competitions. The authorities are highly suggested to pay more attention to such activities.

\subsection{Taking Advantage of Translation Industry}

Although there are well-founded books about the history of Persian Gulf, a small number of them were translated into foreign languages. The authors suggest that the books about the Persian Gulf containing historical information, maps and deeds should be translated into the official languages of the United Nations (Arabic, Chinese, English, French, Russian, and Spanish). In order to do this, Iran's Supreme Cultural Revolution Council must provide the active support, because one of its goals is to formulate and advance policies and strategic plans of the country in different cultural issues.

\section{REFERENCES}

[1] S. Bozorgmehr, Geography of Persian Gulf, Tehran: Abiz Publications, $2^{\text {nd }}$ Chapter, p. 63

[2] M. Ajam, (2011a), Persian Gulf in the Arab Treaties and International Law, Journal of History \& Geography, 155, 2

[3] M. Ajam, (2011b), Persian Gulf in the Arab Treaties and International Law, Journal of History \& Geography, 155, 7

[4] United Nations Group of Experts on Geographical Names (2006), Historical Geographical and Legal Validity of the Name: Persian Gulf, available at: http://unstats.un.org/unsd/geoinfo/ UNGEGN/docs/23-gegn/wp/gegn23wp61.pdf (Accessed: Nov 10, 2016)

[5] A. Madani, 1979, Conviction of Those Who Write "Persian Gulf", Tehran: Toos, pp. 14-15

[6] P. Mojtahedzadeh, (1996a), Name of Persian Gulf in History, political-economic information, vol.10, issue $9 \& 10$, pp. 26-27

[7] P. Mojtahedzadeh, (1996b), Name of Persian Gulf in History, political-economic information, vol.10, issue $9 \& 10$, p. 27

[8] J. Fathi Elahi, 1989, Seminar on Persian Gulf Issues, Institute for Political and International Studies of the Ministry of Foreign Affairs (IPIS), p. 431 